\title{
Effect of Mineral-Based Amendments on Rice (Oryza sativa L.) Growth and Cadmium Content in Plant and Polluted Soil
}

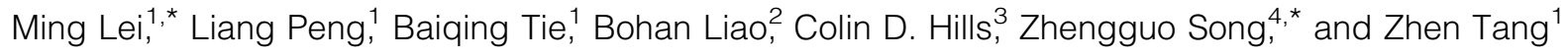 \\ ${ }^{1}$ College of Resource and Environment, Hunan Agricultural University, Changsha, P.R. China. \\ ${ }^{2}$ College of Environment, Central South University of Forestry and Technology, Changsha, P.R. China. \\ ${ }^{3}$ Faculty of Engineering and Science, University of Greenwich, Chatham Maritime, United Kingdom. \\ ${ }^{4}$ Centre for Research in Ecotoxicology and Environmental Remediation, Agro-Environmental Protection Institute, Tianjin, P.R. China.
}

\begin{abstract}
Agricultural soils can be contaminated by industrial activities such as mining and smelting. Contamination with cadmium (Cd) can significantly exceed average background values, which can lead to uptake by rice plant and even harm to humans through food chain. In Hunan province, southern China, rice (Oryza sativa L.) is the main cereal, and human exposure to metallic contaminants through rice pathway is of particular interest. Shortage of land for rice growing means that contaminated agricultural soil is still cultivated for rice in Hunan. In the present work, a field experiment was undertaken to remediate Cd-contaminated paddy soil with three mineral amendments, namely sepiolite, bone char, and a silicon-based product (normally used as fertilizer). Average $\mathrm{Cd}$ concentration in the paddy soil was $2.85 \mathrm{mg} / \mathrm{kg}$, significantly exceeding Chinese soil quality standards of China. Cd content was $0.59 \mathrm{mg} / \mathrm{kg}$ in sepiolite, $0.28 \mathrm{mg} / \mathrm{kg}$ in bone char, and $0.44 \mathrm{mg} / \mathrm{kg}$ in silicon fertilizer, respectively. Distribution fractions of Cd in soil followed the order of exchangeable (FI) $>$ organic matter-bound (FIII) $>$ residual $($ FIV) $>$ oxide-bound (FII) without treatment, while exchangeable $(\mathrm{FI})>$ residual $(\mathrm{FIV})>$ organic matter-bound (FIII) $>$ oxide-bound (FII) after treatment. With addition of three amendments, soil $\mathrm{pH}$ values and rice growth such as plant height and ripening rate increased. Concentrations of $\mathrm{Cd}$ in the rice plant (straw, husk, and unpolished rice) decreased after treatment. However, among three amendments, only the bone char addition reduced $\mathrm{Cd}$ accumulation in the rice plant below the Chinese standard value $(0.2 \mathrm{mg} / \mathrm{kg})$ and in the husk to below the Chinese feed hygiene standard for food $(0.5 \mathrm{mg} / \mathrm{kg})$.
\end{abstract}

Keywords: bone char; cadmium; farmland; rice; sepiolite; silicon fertilizer

\section{Introduction}

$\mathbf{R}$ APID DEVELOPMENT OF THE Chinese economy has resulted in heavy metals pollution (Hu et al., 2014) and food security problem (Lu et al., 2015). In 2014, 19.4\% of farmland was heavily contaminated with heavy metals, including cadmium $(\mathrm{Cd})$, mercury $(\mathrm{Hg})$, arsenic (As), copper $(\mathrm{Cu})$, and lead $(\mathrm{Pb})$, especially $\mathrm{Cd}$ accounting for $7.0 \%$ of the contamination observed (Ministry of Environmental Protection and Ministry of Land and Resources of China, 2014). $\mathrm{Cd}$ is a nonessential element with a mean background level of $0.97 \mathrm{mg} / \mathrm{kg}$ in the environment (Wei et al., 1991). In Hunan province the soil background value is calculated as $0.098 \mathrm{mg} /$

*Corresponding authors: Ming Lei, College of Resource and Environment, Hunan Agricultural University, Changsha 410128, P.R. China. Phone: 0086-731-84618166; Fax: 0086-22-23616890; E-mail: leiming8166@yahoo.com or Zhengguo Song, Centre for Research in Ecotoxicology and Environmental Remediation, Agro-Environmental Protection Institute, Kang Fu Road, Tianjin 300191, P.R. China. Phone: 0086-731-84618166 or 0086-22-23616880; Fax: 0086-73184617803; E-mail: forestman1218@163.com $\mathrm{kg}$ (Pan and Yang, 1988). However, as an industrial byproduct of the mining and smelting of $\mathrm{Pb}$ and zinc, $>680$ tonnes of $\mathrm{Cd}$ are discharged into the environment each year (Kong, 2001). Lei et al. (2010) reported Cd values in garden soil and paddy soil around the vicinity of $\mathrm{Pb} / \mathrm{Zn}$ mines as 10.0 and $11.9 \mathrm{mg} / \mathrm{kg}$, which greatly exceeded soil background values. As a result of this increased availability of $\mathrm{Cd}(\mathrm{Cd}$ is rather soluble), it is easily absorbed by rice roots and concentrated in the rice grain, even on slightly to moderately Cd-polluted soil (Uraguchi et al., 2009). The effect of Cd exposure on human health is significant, causing, for example, "itai-itai" disease (Kobayashi, 1978). Cheng et al. (2005) reported that the amount of Cd-contaminated rice on sale exceeding the national allowable limit of $0.2 \mathrm{mg} / \mathrm{kg}$ was $10.3 \%$ of the total in 2002 (Ministry of Health of China and the Standardization Administration of China, 2005). Specific investigations were also carried out in other provinces such as Hunan (Williams et al., 2009; Lei et al., 2015), Guizhou (Huang et al., 2009), Guangdong (Zhuang et al., 2009; Bian et al., 2013), Zhejiang (Huang et al., 2013), and Jiangsu (Zhao, Zhou et al., 2002; Zhen et al., 2008; Hang et al., 2009; 
Cao et al., 2010). An estimate of the direct economic losses from the effect of $\mathrm{Cd}$ contamination of crops is more than 20 billion RMB (3.20 billion in US\$) (Zhang et al., 2010).

Reduction of Cd entering to the food chain is therefore of great importance for China, especially for Hunan, which is China's biggest rice producer and named "hometown of rice and fish." Although there are some methods such as physical, chemical, and biological methods to remediate contaminated paddy soil, due to the soil being repeatedly reused for the production of rice, few are suitable for remediation of contaminated agricultural soil. Thus, the approach adopted in the present work was to chemically stabilize through an in situ method, using an increase to soil $\mathrm{pH}$ (to reduce Cd mobility) but within limits to ensure that paddy soil remained suitable for rice growing. A number of soil amendments, including limestone, zeolite, or other organic and inorganic amendments, have been investigated for $\mathrm{Cd}$ stabilization (Chen et al., 2000; Geebelen et al., 2006; Huang et al., 2006; Zhao and Masaihiko, 2007). Most of methods using amendments focus on laboratory-scale incubation or pot trials, while few have been applied in the field, as in the present work.

The aims of the present work were as follows: (1) to investigate the effects of sepiolite, bone char, and silicon fertilizer on speciation of $\mathrm{Cd}$ in paddy soil; (2) to examine the effects on $\mathrm{Cd}$ accumulation and translocation in rice plants; and (3) to provide a theoretical and practical basis for a field-scale remediation project to immobilize $\mathrm{Cd}$ to demonstrating rice safety.

\section{Materials and Methods}

\section{Study area}

The contaminated paddy field was located in $\mathrm{Zu}$ Bugan $\left(27^{\circ} 54.686^{\prime} \mathrm{N}, 112^{\circ} 58.296^{\prime} \mathrm{E}\right)$, north of Xiangtan city, Hunan Province. Having been irrigated with contaminated water from Xiangjiang River, the paddy soil was contaminated with Cd, investigated by Tang et al. (2012).

\section{Rice seeds}

One genotype of rice seed named Lu Liang you 611 (L611) was obtained from the Hunan Rice Seed Company following germination in a nursery in April 2015 and planting in May 2015.

\section{Amendments}

There were three amendments chosen for use in this study as follows: sepiolite, bone char, and silicon fertilizer. The natural sepiolite $\left[\mathrm{Mg}_{4} \mathrm{Si}_{6} \mathrm{O}_{15}(\mathrm{OH})_{2} \cdot 6 \mathrm{H}_{2} \mathrm{O}\right]$ sample was purchased from Changsha city, Hunan Province, whereas the bone char was obtained from the Guanghan city, Sichuan Province. The silicon fertilizer was obtained from Tangshan city, Hebei Province, China. As there are no control standards for pollutants in amendments used for agricultural use, the relevant standard for sludge (Ministry of Urban-Rural Development and Environmental Protection of China, 1984) was taken as reference.

\section{Field treatment experimental design}

The paddy field under investigation was divided into ten plots of $30 \mathrm{~m}^{2}$ and separated by polyethylene plates. Every treatment for plot was random design and irrigated through independent irrigation ditch. In the experiment, the depth of soil used for calculating the amendment dosage was $20 \mathrm{~cm}$, which was applied to three replicate plots by manual plowing according to the Table 1, 25 days before planting. On the day of planting, $200 \mathrm{~kg}$ of $\mathrm{P}, \mathrm{K}, \mathrm{N}$ basal fertilizer was added.

The experimental plots were planted with rice seedlings (L611) that had been raised for 4 weeks in clean soil on May 4th, 2015.

They were harvested 90 days later during which all water, fertilizer, and pesticide management continued as normal.

\section{Sample collection and preservation}

Before sowing, $2.0 \mathrm{~kg}$ top-soil sample $(0-20 \mathrm{~cm})$ was collected from the paddy field by soil sampler in February 2015 and placed in polyethylene bags for transportation to the laboratory where they were air-dried. The soils were passed through a 2-mm sieve and stored in $500 \mathrm{~mL}$ polypropylene plastic bottles for analysis.

Samples of the growing rice plants were collected thrice as follows: at the seedling stage, heading stage, and mature stage. At the harvest in July 2015, whole rice plants were pulled, and rice grains and rice straws (above $4 \mathrm{~cm}$ ) were separated from the plant by hand picking/cutting above the roots. The rice plant samples (rice root, straw, and grain) from each area were tagged/labeled, kept in polyethylene bags in the field, and transported to the laboratory, where they were washed with distilled water and then oven dried at $65^{\circ} \mathrm{C}$ for $96 \mathrm{~h}$. The rice root and straw were then cut, milled, and stored for analysis. The rice grain was divided into its husk and unpolished rice, milled, and stored ready for analysis.

\section{Soil, amendments, and rice plant analysis}

The soil $\mathrm{pH}$ was determined using double distilled water (soil: solution ratio $1: 2.5$ ) with a combined $\mathrm{pH}$ electrode, and the cation exchange capacity (CEC) was determined using unbuffered 0.1 M BaCl 2 (Hendershot and Duquette, 1986). Total concentrations of $\mathrm{Cd}$ in paddy soils following acid digestion with $\mathrm{HNO}_{3} / \mathrm{HCl} / \mathrm{HClO}_{4}$ (U.S. EPA, 1998) were determined by Graphite furnace atomic absorption spectrophotometer (AA240FS; Varian).

The amendments were air-dried and ground to pass through a $0.049 \mathrm{~mm}$ mesh sieve. The analysis methods of $\mathrm{pH}$ and $\mathrm{Cd}$ concentrations of amendments were the same as those of soils.

Between 0.1 and $0.2 \mathrm{~g}$ of the rice plant samples (unpolished rice, husk, straw, and root) were weighed into dry clean digestion tubes and moistened overnight with $5 \mathrm{~mL}$ concentrated nitric acid. The following day, the digestion tubes were placed

Table 1. Treatment with Three Amendments

\begin{tabular}{lccc}
\hline & \multicolumn{3}{c}{ Amendments/kg/ha } \\
\cline { 2 - 4 } Treatment ID & Sepiolite & Bone char & $\begin{array}{c}\text { Silicon } \\
\text { fertilizer }\end{array}$ \\
\hline CK & 0 & 0 & 0 \\
Low & $2,250(\mathrm{Sl})^{\mathrm{a}}$ & $2,250(\mathrm{Bl})$ & $450(\mathrm{~F} 1)$ \\
Medium & $11,250(\mathrm{Sm})$ & $11,250(\mathrm{Bm})$ & $900(\mathrm{~F} 1)$ \\
High & $22,500(\mathrm{Sh})$ & $22,500(\mathrm{Bh})$ & $2,250(\mathrm{~F} 1)$ \\
\hline
\end{tabular}

${ }^{\mathrm{a}}$ The letters in bracket are treatment with each amendment and its concentration. 
on a heating block and heated at $80^{\circ} \mathrm{C}$ for $3 \mathrm{~h}$ and then at $120^{\circ} \mathrm{C}$ for $48 \mathrm{~h}$ until a little solution remained without completely drying out. After the tubes had cooled, the digests were transferred to $25 \mathrm{~mL}$ flasks with deionized water and filtered into polythene bottles. Total Cd concentrations in root, straw, husk, and unpolished rice were determined by Graphite furnace atomic absorption spectrophotometer (AA240FS; Varian).

\section{Cd speciation of soil analysis}

To assess the effectiveness of amendments for in situ immobilization, the sequential extraction scheme proposed by European Community Bureau of Reference (BCR method), including exchangeable (FI), oxide-bound (FII), organic matter-bound (FIII), and residual (FIV) (Ure et al., 1993), was used to analyze the Cd fractionations in preamended and postamended soil samples. The detail of the BCR method was described in reference (Ure et al., 1993). The determinations of $\mathrm{Cd}$ in the extracts were performed by Graphite furnace atomic absorption spectrophotometer (AA240FS; Varian).

Extraction efficiencies of the sequential extraction procedures were expressed as percentage of the total contents, estimated by the following equation:

$$
E(\%)=\frac{\sum C_{F i}}{T_{C}} \times 100 \%
$$

where $E(\%)$ represents the extraction efficiency of Cd with BCR method, $C_{F i}(\mathrm{mg} / \mathrm{kg})$ is the average concentration of each fraction of $\mathrm{Cd}$, and $T_{c}$ is the total content of $\mathrm{Cd}$ in soil $(\mathrm{mg} / \mathrm{kg})$.

\section{Statistical analysis}

All treatments were replicated thrice in the experiments. The means and standard deviation (SD) values were calculated by Microsoft Office Excel 2007. One-way analysis of variance was carried out with SPSS16.0. A significant difference ( $p<0.05$ or $p<0.01)$ was observed between treatments.

\section{Results}

\section{Properties of soil and amendments}

The selected physicochemical properties of the paddy soil and three amendments are presented in Table 2 . The paddy soil called the Quaternary Red Clay is highly weathered parent material with slightly acidic $\mathrm{pH}=5.13$, suggesting that the paddy soil was acidic easily increasing $\mathrm{Cd}$ availability and accumulation in rice. The average $\mathrm{Cd}$ concentration in paddy soil is $2.85 \pm 0.29 \mathrm{mg} / \mathrm{kg}$ in dry weight. With reference to the Chinese environmental quality standards for heavy metals in soil, the mean concentration of Cd $(2.85 \pm 0.29 \mathrm{mg} /$ $\mathrm{kg}$ ) recorded for paddy soil in this study was $\sim 10$ times higher than $0.3 \mathrm{mg} / \mathrm{kg}$ (GB15618-1995), indicating the seriousness of the contamination. Furthermore, the concentrations of $\mathrm{Cd}$ in three amendments are low $(0.28-0.59 \mathrm{mg} / \mathrm{kg})$ and were lower than the permissible reference standards of Cd for agricultural use (GB4284-1984), indicating that they could be used in practice. The $\mathrm{pH}$ values of three amendments were extremely different. The bone char has the highest $\mathrm{pH}$ value with 10.79 , followed by sepiolite $(\mathrm{pH}=8.29)$, indicating that bone char and sepiolite were alkaline materials. The lowest $\mathrm{pH}$ value of silicon fertilizer was 5.63, as same as soil $\mathrm{pH}$ value.

\section{Changes in soil $\mathrm{pH}$}

The effects of three amendments on soil $\mathrm{pH}$ are shown in Fig. 1, and it can be found that the nonamended soil (CK) had a low $\mathrm{pH}$ of 5.13 before planting. After application, the $\mathrm{pH}$ values of soils significantly $(p<0.05)$ increased from that of $\mathrm{CK}$ with increasing amounts of amendments. Due to it containing calcium carbonate $\left(\mathrm{CaCO}_{3}\right)$, the addition of bone char led to a marked increase in soil $\mathrm{pH}$ (5.50-6.47) compared with the control $(p<0.05)$. Addition of bone char has caused much bigger increase of soil $\mathrm{pH}$ than sepiolite ( $\mathrm{pH}$ 5.25-5.77) and silicon fertilizer ( $\mathrm{pH}$ 5.18-5.50) did.

\section{Cd fraction distribution}

According to the Equation (1), the fraction distributions of $\mathrm{Cd}$ in paddy soils before and after amendment are shown in Fig. 2. The distributions of $\mathrm{Cd}$ in unamended paddy soil followed: FI > FIII > FIV > FII $(51.32 \%, 22.87 \%, 19.50 \%$, and $6.30 \%$, respectively), highlighting the bioavailability of $\mathrm{Cd}$. After the amendments were applied, the order of fraction distribution of $\mathrm{Cd}$ changed to: FI $>$ FIV $>$ FIII $>$ FII. The average ratios of FI and FIII decreased by: $7.51 \%$ and $1.41 \%$ with sepiolite, $6.02 \%$ and $1.81 \%$ with bone char, and $8.04 \%$ and $1.57 \%$ with silicon fertilizer. The average percentages of

Table 2. Properties of Soll and Amendments

\begin{tabular}{|c|c|c|c|c|c|}
\hline Material names & $p H$ & $\begin{array}{c}\text { CEC, } \\
\mathrm{cmol} / \mathrm{kg}\end{array}$ & $\begin{array}{c}\text { Organic } \\
\text { matter, } g / k g\end{array}$ & $\begin{array}{c}\text { Cd concentration, } \\
m g / k g\end{array}$ & Main component \\
\hline Red soil & 5.13 & 19.32 & 15.90 & $2.85 \pm 0.29$ & \\
\hline Sepiolite & 8.29 & & & 0.59 & $\mathrm{CaO} 41.7 \%, \mathrm{SiO}_{2} 32.5 \%, \mathrm{MgO} 16.8 \%$ \\
\hline Bone char & 10.79 & & & 0.28 & $\mathrm{CaO} 56.46 \%, \mathrm{SiO}_{2} 0.06 \%, \mathrm{P}_{2} \mathrm{O}_{5} 39.8 \%$ \\
\hline Silicon fertilizer & 5.63 & & & 0.44 & $\mathrm{SiO}_{2} \% 25 \%, \mathrm{CaO} 20 \%, \mathrm{~K}_{2} \mathrm{O} 5 \%, \mathrm{MgO} 10 \%$ \\
\hline EQSHMS $^{\mathrm{a}}$ & $<6.5$ & & & 0.3 & \\
\hline \multirow[t]{2}{*}{ CSPSAU $^{\mathrm{b}}$} & $\mathrm{pH}<6.5$ & & & $<5$ & \\
\hline & $\mathrm{pH} \geq 6.5$ & & & $<20$ & \\
\hline
\end{tabular}

${ }^{a}$ EQSHMS means Environmental Quality Standards for Heavy Metals in Soils (GB15618-1995 Grade 2) (Ministry of Environmental Protection of China, 1995).

${ }^{\mathrm{b}}$ CSPSAU means Control Standards for Pollutants in Sludges from Agricultural Use (GB4284-1984) (Ministry of Urban-Rural Development and Environmental Protection of China, 1984).

Cd, cadmium; CEC, cation exchange capacity. 
FIG. 1. Soil $\mathrm{pH}$ in control (CK) and after amendments with sepiolite (Sl, Sm, Sh), bone char (Bl, $\mathrm{Bm}, \mathrm{Bh})$, and silicon fertilizer ( $\mathrm{Fl}$, $\mathrm{Fm}, \mathrm{Fh}$ ).

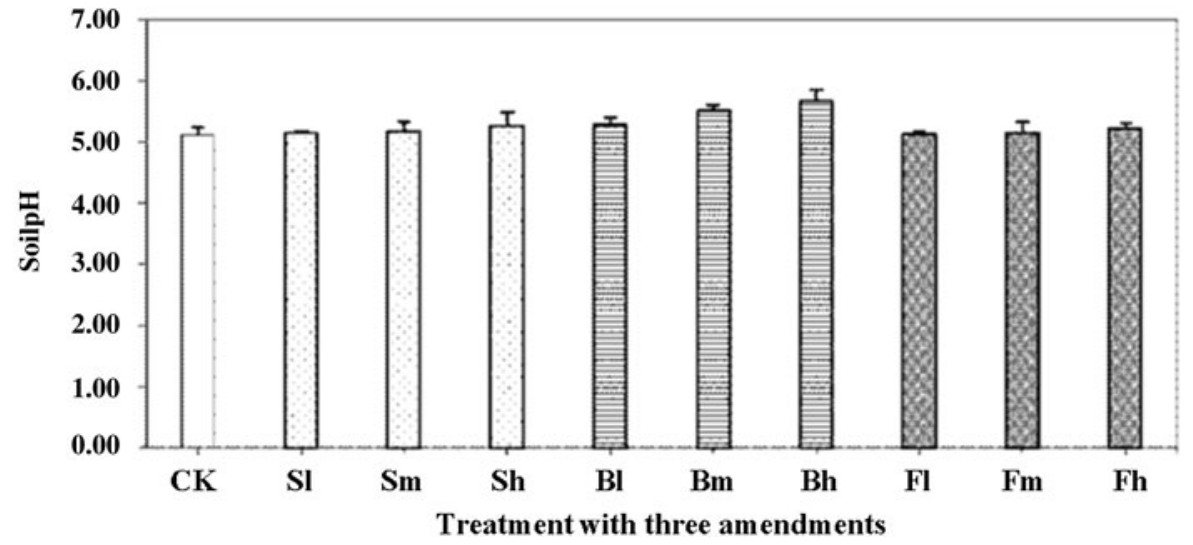

FII and FIV increased by: $1.41 \%, 1.81 \%$, and $1.57 \%$ and $7.60 \%, 8.81 \%$, and $9.38 \%$ with application of sepiolite, bone char, and silicon fertilizer, respectively. Moreover, as amendment dosage increased $\mathrm{Cd}$ immobilization increased.

\section{Rice plant growth}

Indicators of rice plant growth, including plant height, total of grains per ear, and weight of a thousand grains, are shown in Table 3. There were significant impacts on rice growth, including plant height and ripening rate with the silicon fertilizer. At higher dosage rates, the plant height and ripening rate of rice were $3.7 \%$ and $4.2 \%$ times higher than those of control (CK), respectively. The ripening rate was the highest, ranging from $83.2 \%$ to $86.8 \%$ for rice L611 with silicon fertilizer treatment, followed by bone char from $82.9 \%$ to $84.1 \%$. There were no obvious effects on the aggregate weight of grains with or without treatment.

\section{Cd concentration in rice roots and straws}

Concentrations of $\mathrm{Cd}$ in the roots and straws of rice plants, including as seeding at the heading and mature stages are shown in Table 4. In comparison with $\mathrm{CK}$, the $\mathrm{Cd}$ contents (in roots and straws) were significantly influenced by the amendments showing both negative and positive relationships at different growth stages. In the mature stage, the ranges of reduction of $\mathrm{Cd}$ in rice straws were 23.0$53.1 \%$ with sepiolite treatment, $26.7-52.0 \%$ with bone char treatment, and 25.2-61.2\% with the silicon fertilizer treatment, respectively. The order of effect of amendments on reduction of $\mathrm{Cd}$ in rice straw was silicon fertilizer ( $\mathrm{Sh}$ and $\mathrm{Sm})>$ sepiolite $(\mathrm{Sh})>$ bone char $(\mathrm{Bh})$. However, the concentrations of $\mathrm{Cd}$ in the rice roots increased with two treatment levels (S1 and Sm) of sepiolite, three levels (B1, $\mathrm{Bm}$, and $\mathrm{Bh}$ ) of bone char, and two levels (Sl and Sm) of silicon fertilizer.

\section{Cd concentration in rice grain}

Effects of the three amendments on $\mathrm{Cd}$ in rice husk and unpolished rice are shown in Table 5. The $\mathrm{Cd}$ found in rice grains, including unpolished rice and husk, reduced with increasing amendment dosage. The Cd contents in unpolished rice and husk without amendments $(\mathrm{CK})$ were 0.50 and $0.57 \mathrm{mg} / \mathrm{kg}$, which exceeded the maximum permissible level for Chinese foods (GB2762-2005) and the permissible level for the Chinese hygiene standard for feed (GB13078-2001), respectively. The negative relationship between $\mathrm{Cd}$ in rice grains (unpolished rice and husk) and amendment application rate was for unpolished rice: $22.5 \%(\mathrm{Sl}), 46.8 \%(\mathrm{Sm})$, and $52.8 \%(\mathrm{Sh})$ for sepiolite; $43.6 \%(\mathrm{Bl}), 47.6 \%(\mathrm{Bl})$, and $67.5 \%$ (Bh) for bone char; and $53.6 \%(\mathrm{Fl}), 41.9 \%(\mathrm{Fm})$, and $54.8 \%$ (Fh) for silicon fertilizer, respectively, indicating that the lowest contents of $\mathrm{Cd}$ were in unpolished rice treatment with the highest amounts of three amendments, especially bone char, followed by silicon fertilizer.

\section{Discussions}

With reference to the Chinese environmental quality standards for heavy metals in soil, the mean concentration of
FIG. 2. Cd fractions in soil amended with sepiolite, bone char, and silicate fertilizer. $\mathrm{Cd}$, cadmium.

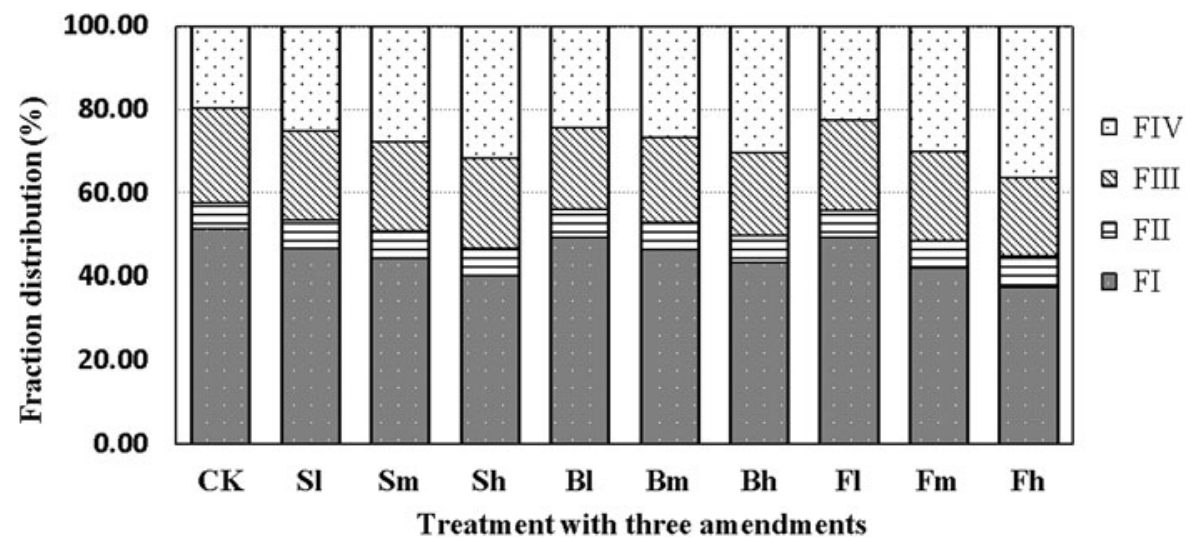


Table 3. Rice Plant Growth

\begin{tabular}{|c|c|c|c|c|c|c|}
\hline $\begin{array}{l}\text { Treatment } \\
\text { codes }\end{array}$ & Amendments & $\begin{array}{c}\text { Plant } \\
\text { height, } \mathrm{cm}\end{array}$ & $\begin{array}{l}\text { Total grain } \\
\text { per ear }\end{array}$ & $\begin{array}{l}\text { Filled grains } \\
\text { per panicle }\end{array}$ & $\begin{array}{l}\text { Ripening } \\
\text { rate, \% }\end{array}$ & $\begin{array}{l}\text { Weight of a } \\
\text { thousand grain, } g\end{array}$ \\
\hline CK & Without amendment & $84.6 \pm 0.03$ & $105.7 \pm 0.12$ & $87.3 \pm 0.06$ & $82.6 \pm 0.08$ & $23.5 \pm 0.12$ \\
\hline Sl & Sepiolite & $82.4 \pm 0.05$ & $105.3 \pm 0.10$ & $86.0 \pm 0.13$ & $81.7 \pm 0.08$ & $22.8 \pm 0.13$ \\
\hline $\mathrm{Sm}$ & & $83.3 \pm 0.11$ & $106.3 \pm 0.09$ & $86.4 \pm 0.16$ & $81.3 \pm 0.03$ & $23.7 \pm 0.06$ \\
\hline Sh & & $85.7 \pm 0.07$ & $105.2 \pm 0.12$ & $87.8 \pm 0.14$ & $83.5 \pm 0.11$ & $24.1 \pm 0.04$ \\
\hline $\mathrm{Bl}$ & Bone char & $85.1 \pm 0.03$ & $106.5 \pm 0.17$ & $88.3 \pm 0.05$ & $82.9 \pm 0.04$ & $24.3 \pm 0.08$ \\
\hline $\mathrm{Bm}$ & & $86.7 \pm 0.06$ & $105.9 \pm 0.10$ & $88.3 \pm 0.07$ & $83.4 \pm 0.06$ & $23.5 \pm 0.15$ \\
\hline $\mathrm{Bh}$ & & $87.2 \pm 0.12$ & $106.2 \pm 0.11$ & $89.3 \pm 0.10$ & $84.1 \pm 0.05$ & $24.3 \pm 0.09$ \\
\hline $\mathrm{Fl}$ & Silicon fertilizer & $83.8 \pm 0.21$ & $105.1 \pm 0.04$ & $87.4 \pm 0.04$ & $83.2 \pm 0.06$ & $23.8 \pm 0.10$ \\
\hline Fm & & $85.3 \pm 0.07$ & $106.2 \pm 0.11$ & $87.4 \pm 0.11$ & $84.9 \pm 0.10$ & $22.9 \pm 0.04$ \\
\hline $\mathrm{Fh}$ & & $87.7 \pm 0.08$ & $105.9 \pm 0.05$ & $91.9 \pm 0.03$ & $86.8 \pm 0.07$ & $24.2 \pm 0.08$ \\
\hline
\end{tabular}

Cd $(2.85 \pm 0.29 \mathrm{mg} / \mathrm{kg})$ recorded for paddy soil in this study was $\sim 10$ times higher than $0.3 \mathrm{mg} / \mathrm{kg}$ (GB15618-1995), indicating the seriousness of the contamination. Furthermore, the paddy soil was acidic causing soil $\mathrm{Cd}$ availability and accumulation in rice. Following the BCR method, the (combined exchangeable- and carbonate fractions) first exchangeable fraction of the four followed: FI $>$ FIII $>$ FIV $>$ FII, clearly indicating the bioavailability of this metal.

Although there are mitigation methods for $\mathrm{Cd}$ contaminated soil available, including soil washing, phytoremediation, and chemical immobilization, these can impact negatively on agricultural soils rendering them unusable. However, the in situ treatments used in this work reduced the bioavailability of $\mathrm{Cd}$ in the paddy soil without adversely affecting rice yield. The three amendments were within the permissible reference standards for agricultural use (GB4284-1984), indicating that they could be used in practice. Previous studies have shown that the application of alkaline substances containing $\mathrm{Ca}, \mathrm{Mg}$, and $\mathrm{Si}$ significantly reduced the availability of $\mathrm{Cd}$ in paddy soil and its uptake by rice through change in soil $\mathrm{pH}$ (Welch and Norvell, 1999; Zhao, Hamon et al., 2002). This is also shown by the present study with increasing amounts of amendments, especially with bone char, followed by sepiolite. An increasing amount of amendment (and consequently rise in soil $\mathrm{pH}$ ) reduced the bioavailability of Cd (Li et al., 2008; Gu et al., 2011; Liang et al., 2014; Zhen et al., 2015). Of the four exchangeable "fractions," the percentages of FI and FIII decreased, whereas FII and FIV increased upon amendment. That said, the dominant exchangeable fraction was FI, followed by residual fraction (FIV), as soil parameters such as organic matter, CEC, soil texture and soil microbiota, and redox potential also affect $\mathrm{Cd}$ availability under field conditions.

As bioavailability of $\mathrm{Cd}$ decreased upon treatment, plant height and rice ripening rate increased. A decrease in $\mathrm{Cd}$ in rice roots and straws was seen at each growth stage and in unpolished rice and husk also. The concentrations of $\mathrm{Cd}$ in unpolished rice without amendments $(0.50 \mathrm{mg} / \mathrm{kg})$ exceeded the maximum permissible level for Chinese foods (GB27622005) and in husk exceeded the permissible level of the Chinese hygiene standard for feed (GB13078-2001). Takijima and Katsumi (1973) reported that Cd uptake by plant was reduced remarkably by raising the soil $\mathrm{pH}$. In the present study, the ranges of concentrations of $\mathrm{Cd}$ in unpolished rice were $0.24-0.39 \mathrm{mg} / \mathrm{kg}$ with sepiolite treatment, 0.16 $0.28 \mathrm{mg} / \mathrm{kg}$ with bone char treatment, and $0.23-0.29 \mathrm{mg} / \mathrm{kg}$ with silicon fertilizer treatment. The Cd content of unpolished rice with the highest bone char addition $(22,500 \mathrm{~kg} / \mathrm{ha})$ met the food quality standard value of China $(0.2 \mathrm{mg} / \mathrm{kg})$, while the doses of amendments used in this study were high. With the existing contents of other amendment treatment, Cd concentrations $(0.23-0.39 \mathrm{mg} / \mathrm{kg})$ were slightly above the standard limit value for food. Husk is normally used to feed pigs and cows in southern China, and the values were recorded after the addition if amendments in this study $(0.38$ $0.49 \mathrm{mg} / \mathrm{kg}$ ) met the limit value for feed hygiene standards (GB13078-2001). This clearly indicated that Cd in unpolished rice was lowest with the highest application rates,

Table 4. Cadmium Concentration in Rice Roots and Straws

\begin{tabular}{|c|c|c|c|c|c|c|c|}
\hline \multirow{2}{*}{$\begin{array}{l}\text { Treatment } \\
\text { codes }\end{array}$} & \multirow[b]{2}{*}{ Amendments } & \multicolumn{2}{|c|}{ Seeding stage $(\mathrm{mg} / \mathrm{kg})$} & \multicolumn{2}{|c|}{ Heading stage $(\mathrm{mg} / \mathrm{kg})$} & \multicolumn{2}{|c|}{ Mature stage $(\mathrm{mg} / \mathrm{kg})$} \\
\hline & & Root & Shoot & Root & Shoot & Root & Shoot \\
\hline $\mathrm{CK}$ & Without amendment & $8.22 \pm 1.76$ & $0.55 \pm 0.08$ & $1.43 \pm 0.37$ & $0.54 \pm 0.12$ & $6.85 \pm 1.43$ & $4.69 \pm 0.85$ \\
\hline $\mathrm{Sl}$ & Sepiolite & $5.83 \pm 0.73$ & $0.47 \pm 0.08$ & $1.12 \pm 0.21$ & $0.25 \pm 0.07$ & $12.4 \pm 0.10$ & $3.61 \pm 0.70$ \\
\hline $\mathrm{Sm}$ & & $5.22 \pm 1.33$ & $0.37 \pm 0.09$ & $0.99 \pm 0.24$ & $0.20 \pm 0.03$ & $10.3 \pm 1.47$ & $2.31 \pm 0.27$ \\
\hline Sh & & $4.07 \pm 0.95$ & $0.31 \pm 0.03$ & $0.79 \pm 0.11$ & $0.17 \pm 0.04$ & $6.65 \pm 1.32$ & $2.20 \pm 0.31$ \\
\hline $\mathrm{B} 1$ & Bone char & $4.77 \pm 1.15$ & $2.14 \pm 0.15$ & $0.80 \pm 0.05$ & $0.33 \pm 0.21$ & $7.46 \pm 0.90$ & $3.44 \pm 0.48$ \\
\hline $\mathrm{Bm}$ & & $3.62 \pm 0.71$ & $1.81 \pm 0.36$ & $1.20 \pm 0.28$ & $0.16 \pm 0.03$ & $6.76 \pm 0.91$ & $3.05 \pm 0.57$ \\
\hline $\mathrm{Bh}$ & & $2.32 \pm 0.53$ & $1.16 \pm 0.27$ & $0.70 \pm 0.03$ & $0.15 \pm 0.04$ & $6.99 \pm 1.15$ & $2.25 \pm 0.15$ \\
\hline $\mathrm{Fl}$ & Silicon fertilizer & $3.69 \pm 0.19$ & $1.84 \pm 0.09$ & $1.03 \pm 0.13$ & $0.17 \pm 0.03$ & $9.35 \pm 0.82$ & $3.51 \pm 0.80$ \\
\hline Fm & & $4.27 \pm 0.67$ & $0.57 \pm 0.12$ & $0.86 \pm 0.13$ & $0.16 \pm 0.04$ & $7.75 \pm 2.06$ & $1.82 \pm 0.55$ \\
\hline $\mathrm{Fh}$ & & $3.52 \pm 1.46$ & $0.51 \pm 0.18$ & $0.70 \pm 0.18$ & $0.15 \pm 0.02$ & $6.01 \pm 2.70$ & $1.86 \pm 0.37$ \\
\hline
\end{tabular}


Table 5. CAdmium Concentrations in Husk and Unpolished Rice Treated with Amendments

\begin{tabular}{llcc}
\hline \multirow{2}{*}{$\begin{array}{l}\text { Treatment } \\
\text { codes }\end{array}$} & & \multicolumn{2}{c}{ Cd concentrations $(\mathrm{mg} / \mathrm{kg})$} \\
\cline { 3 - 4 } CK & Amendments & Husk & Unpolished rice \\
& Without & $0.57 \pm 0.12$ & $0.50 \pm 0.10$ \\
Sl & amendment & & \\
Sm & Sepiolite & $0.49 \pm 0.18$ & $0.39 \pm 0.13$ \\
Sh & & $0.41 \pm 0.28$ & $0.27 \pm 0.16$ \\
Bl & Bone char & $0.41 \pm 0.19$ & $0.24 \pm 0.17$ \\
Bm & & $0.43 \pm 0.17$ & $0.28 \pm 0.10$ \\
Bh & & $0.39 \pm 0.28$ & $0.26 \pm 0.12$ \\
Fl & Silicon fertilizer & $0.48 \pm 0.14$ & $0.16 \pm 0.04$ \\
Fm & & $0.46 \pm 0.13$ & $0.23 \pm 0.16$ \\
Fh & & $0.41 \pm 0.18$ & $0.23 \pm 0.11$ \\
\end{tabular}

showing the order: bone char followed by silicon fertilizer and sepiolite.

\section{Conclusions}

Concentrations of $\mathrm{Cd}$ in the paddy soil from $\mathrm{Zu}$ Bugan, Xiangtan, Hunan Province significantly exceeded the Chinese standard value for soil and this caused $\mathrm{Cd}$ to be accumulated in rice plants. The fractionation distributions of $\mathrm{Cd}$ analyzed using the BCR method showed that the dominant $\mathrm{Cd}$ species was readily exchangeable. The $\mathrm{pH}$ of soil and the residual fraction of $\mathrm{Cd}$ increased with the increasing addition of sepiolite, bone char, and silicon fertilizer. Rice plant height and ripening rate increased in comparison to plants grown in soil without amendments, and $\mathrm{Cd}$ concentrations decreased with increasing amounts of the three amendments; only the highest bone char addition was capable of reducing $\mathrm{Cd}$ to meet the food standard of China. This work has demonstrated that it is possible to reduce bioavailable $\mathrm{Cd}$ in rice grown in grossly contaminated soil to meet food quality standards. However, more work is required to see how the amendments may be modified or augmented to increase their efficacy at lower dosages.

\section{Acknowledgments}

This work was supported by the National Science Foundation of China (21007014/B0702), Ministry of Environment Protection's Special Fund for Scientific Research in the Public Interest (201009047), Key Laboratory of Production Environment and Agro-product Safety of Ministry of Agriculture and Tianjin Key Laboratory of Agro-environment and Food Safety (2010-KJ-KF-03), and by Central Public Research Institutes Basic Funds for Research and Development (Agro-Environmental Protection Institute, Ministry of Agriculture, P.R. China).

\section{Author Disclosure Statement}

No competing financial interests exist.

\section{References}

Bian, R., Chen, D., Liu, X., Cui, L., Li, L., Pan, G., Xie, D., Zheng, J., Zhang, X., Zheng, J., and Chang, A. (2013). Bio- char soil amendment as a solution to prevent Cd-tainted rice from China: Results from a cross-site field experiment. Ecol. Eng. 58, 378.

Cao, H.B., Chen, J.J., Zhang, J., Zhang, H., Qiao, L., and Men, Y. (2010). Heavy metals in rice and garden vegetables and their potential health risks to inhabitants in the vicinity of an industrial zone in Jiangsu, China. J. Environ. Sci. 22, 1792.

Chen, H.M., Zheng, C.R., Tu, C., and Shen, Z.G. (2000). Chemical methods and phytoremediation of soil contaminated with heavy metals. Chemosphere 41, 229.

Cheng, W.D., Yao, H.G., Wu, W., and Zhang, G.P. (2005). Heavy metal pollution and its countermeasures in soil-rice system. Rev. Chin. Agric. Sci. Technol. 7, 51.

Geebelen, W., Sappin-Didier, V., Ruttens, A., Carleer, R., Yperman, J., Bongué-Boma, K., Mench, M., van der Lelie, N., and Vangronsveld, J. (2006). Evaluation of cyclonic ash, commercial Na-silicates, lime and phosphoric acid for metal immobilisation purposes in contaminated soils in Flanders (Belgium). Environ. Pollut. 144, 32.

Gu, H.H., Qiu, H., Tian, T., Zhan, S.S., Deng, T.H.B., Chaney, R.L., Wang, S.Z., Tang, Y.T., Morel, J.L., and Qiu, R.L. (2011). Mitigation effects of silicon rich amendments on heavy metal accumulation in rice (Oryza sativa L.) planted on multi-metal contaminated acidic soil. Chemosphere 83, 1234.

Hang, X.S., Wang, H.Y., Zhou, J.M., Ma, C.L., Du, C.W., and Chen, X.Q. (2009). Risk assessment of potentially toxic element pollution in soils and rice (Oryza sativa) in a typical area of the Yangtze river delta. Environ. Pollut. 157, 2542.

Hendershot, W.H., and Duquette, M. (1986). A sample barium chloride method for determining cation exchange capacity and exchangeable cations. Soil Sci. Soc. Am. J. 50, 606.

$\mathrm{Hu}, \mathrm{H}$., Jin, Q., and Kavan, P. (2014). A study of heavy metal pollution in China: Current status, pollution-control policies and countermeasures. Sustainability 6, 5820.

Huang, X.F., Hu, J.W., Li, C.X., Deng, J.J., Long, J., and Qin, F.X. (2009). Heavy-metal pollution and potential ecological risk assessment of sediments from Baihua Lake, Guizhou, P.R. China. Int. J. Environ. Health Res. 19, 405.

Huang, Y.Z., Hu, Y., Liu, Y.X., and Zhu, Y.G. (2006). Effects of bone char on uptake and accumulation of heavy metals by three rice genotypes (Oryza sativa L.) [in Chinese]. J. Agro Environ. Sci. 25, 1481.

Huang, Z., Pan, X.D., Wu, P.G., Han, J.L., and Chen, Q. (2013). Health risk assessment of heavy metals in rice to the population in Zhejiang, China. PLoS One 8, e75007.

Kobayashi, J. (1978). Pollution by cadmium and the itai-itai disease in Japan. In F.W. Oehme, Ed., Toxicity of Heavy Metals in the Environment, Part 1. New York: Marcel Dekker, p. 47.

Kong, Q.H. (2001). Human health effects for environ-mental cadmium pollution [in Chinese]. J. Zhejiang Acad. Med. Sci. 12,1 .

Lei, M., Tie, B.Q., Song, Z.G., Liao, B.H., Lepo, J.E., and Huang, Y.Z. (2015). Heavy metal pollution and potential health risk assessment of white rice around mine areas in Hunan Province, China. Food Sec. 7, 45.

Lei, M., Zhang, Y., Khan, S., Qin, P.F., and Liao, B.H. (2010). Pollution, fractionation, and mobility of $\mathrm{Pb}, \mathrm{Cd}, \mathrm{Cu}$, and $\mathrm{Zn}$ in garden and paddy soils from a $\mathrm{Pb} / \mathrm{Zn}$ mining area. Environ. Monit. Assess. 168, 215.

Li, P., Wang, X.X., Zhang, T.L., Zhou, D.M., and He, Y.Q. (2008). Effects of several amendments on rice growth and uptake of copper and cadmium from a contaminated soil. $J$. Environ. Sci. 20, 449. 
Liang, X.F., Han, J., Xu, Y.M., Sun, Y.B., Wang, L., and Tan, X. (2014). In situ field-scale remediation of $\mathrm{Cd}$ polluted paddy soil using sepiolite and palygorskite. Geoderma 235, 9.

Lu, Y.L., Jenkins, A., Ferrier, R.C., Bailey, M., Gordon, I.J., Song, S., Huang, J.K., Jia, S.F., Zhang, F.S., Liu, X.J., Feng, Z.Z., and Zhang, Z.B. (2015). Addressing China's grand challenge of achieving food security while ensuring environmental sustainability. Sci. Adv. 1, e1400039.

Ministry of Environmental Protection and Ministry of Land and Resources of China. (2014). National Survey of Soil Pollution Bulletin [in Chinese]. Beijing.

Ministry of Environmental Protection of China. (1995). Environmental quality standard for soils (GB15618-1995, Ministry of Environmental Protection of China, Grade 2) [in Chinese].

Ministry of Health of China and the Standardization Administration of China. (2005). Maximum levels of contaminants in foods (GB2762-2005) [in Chinese]. Beijing: China Standardization Press.

Ministry of Urban-Rural Development and Environmental Protection of China. (1984). Control standards for pollutants in sludges from agricultural use (GB4284-1984, Ministry of Urban-Rural Development and Environmental Protection of China) [in Chinese].

National Feed Industry Standardization Technical Committee of China. (2001). Hygienical standard for feeds (GB13078-2001, National Feed Industry Standardization Technical Committee of China) [in Chinese].

Pan, Y.M., and Yang, G.Z. (1988). Research Method and Soil Background Value of Hunan [in Chinese]. Beijing: Chinese Environmental Science Press, p. 338.

Takijima, Y., and Katsumi, F. (1973). Cadmium contamination of soils and rice plants caused by zinc mining I. Production of high cadmium rice on the paddy fields in lower reaches of the mine station. Soil Sci. Plant Nutr. 19, 29.

Tang, Z., Yang, R.B., Lei, M., Tang, S.R., Song, Z.G., and Peng, S. (2012). Risk assessment of Cd in paddy soil and rice sample collected from an industrial park of Xiangtan [in Chinese]. J. Hunan Agric. Univ. Nat. Sci. 38, 92.

Uraguchi, S., Mori, S., Kuramata, M., Kawasaki, A., Arao, T., and Ishikawa, S. (2009). Root-to-shoot Cd translocation via the xylem is the major process determining shoot and grain cadmium accumulation in rice. J. Exp. Bot. 60, 2677.

Ure, A.M., Quevauviller, P.H., Muntau, H., and Griepink, B. (1993). Speciation of heavy metals in soils and sediments. An account of the improvement and harmonization of extraction techniques undertaken under the auspices of the BCR of Commission of the European Communities. Intern. J. Environ. Anal. Chem. 51, 5.

U.S. EPA. (2007). Method 3051A: Microwave Assisted Acid Digestion of Sediments, Sludges, Soils and Oils. Available at: https://www.epa.gov/sites/production/files/2015-12/documents/ 3051a.pdf

Wei, F.S., Chen, J.S., Wu, Y.Y., and Zheng, C.J. (1991). Study on the background contents on 61 elements of soils in China. Chin. J. Environ. Sci. 12, 12.

Welch, R.M., and Norvell, W.A. (1999). Mechanisms of cadmium uptake, translocation and deposition in plants. In M.J. McLaughlin and B.R. Singh, Eds., Cadmium in Soils and Plants. Dordrecht: Kluwer Academic, p. 125.

Williams, P.N., Lei, M., Sun, G.X., Huang, Q., Lu, Y., Deacon, C., Meharg, A.A., and Zhu, Y.G. (2009). Occurrence and partitioning of cadmium, arsenic and lead in mine impacted paddy rice: Hunan, China. Environ. Sci. Technol. 43, 637.

Zhang, Z., Lu, K., and Meng, Q.F. (2010). Research progress and control countermeasures of heavy metal in vegetables [in Chinese]. J. Ningbo Univ. Nat. Sci. Eng. Ed. 23, 22.

Zhao, F.J., Hamon, R.E., Lombi, E., McLaughlin, M.J., and McGrath, S.P. (2002). Characteristics of cadmium uptake in two contrasting ecotypes of the hyperaccumulator Thlaspi caerulescens. J. Exp. Bot. 53, 535.

Zhao, Q.G., Zhou, B.Z., and Yang, H. (2002). Study on environmental quality and agricultural safety of Jiangsu province, China [in Chinese]. Soil 1, 1.

Zhao, X.L., and Masaihiko, S. (2007). Amelioration of cadmium polluted paddy soils by porous hydrated calcium silicate. Water Air Soil Pollut. 183, 309.

Zhen, R.L., Chen, Z., Cai, C., Tie, B.Q., Liu, X.L., Reid, B.J., Huang, Q., Lei, M., Sun, G.X., and Balterenaite, E. (2015). Mitigating heavy metal accumulation into rice (Oryza sativa L.) using biochar amendment-a field experiment in Hunan, China. Environ. Sci. Pollut. Res. 22, 11097.

Zhen, Y.H., Cheng, Y.J., Pan, G.X., and Li, L.Q. (2008). Cd, Zn and Se content of the polished rice samples from some Chinese open markets and their relevance to food safety. J. Saf. Environ. 8, 119.

Zhuang, P., McBride, M.B., Xia, H., Li, N., and Li, Z. (2009). Health risk from heavy metals via consumption of food crops in the vicinity of Dabaoshan mine, South China. Sci. Total Environ. 407, 1551. 